\title{
Isolated traumatic innominate artery dissection: an exceedingly rare entity!
}

\author{
Amit Ajit Deshpande () ,' Sumit Agasty, ${ }^{2}$ Sanjeev Kumar, ${ }^{1}$ Pradeep Ramakrishnan ${ }^{2}$
}

${ }^{1}$ Cardiovascular Radiology \& Endovascular Interventions, All India Institute of Medical Sciences, New Delhi, India ${ }^{2}$ Cardiothoracic and Vascular Surgery, All India Institute of Medical Sciences, New Delhi, India

\section{Correspondence to}

Dr Sanjeev Kumar;

sanjeevradio@gmail.com

Accepted 19 February 2021

Check for updates

(c) BMJ Publishing Group Limited 2021. No commercial re-use. See rights and permissions. Published by BMJ.

To cite: Deshpande AA, Agasty S, Kumar S, et al. BMJ Case Rep 2021;14:e241710. doi:10.1136/bcr-2021-

241710

\section{DESCRIPTION}

A 22-year-old boy presented in the emergency department with the history of road traffic accident while driving a car. He was haemodynamically stable, with CT showing innominate artery (IA) ostial dissection with pseudoaneurysm formation (figure 1). He also suffered lung contusions, multiple rib fractures and pneumomediastinum. There was no abdominal visceral injury.

The IA injury was managed with an open repair. Haematoma and adhesions were noted intraoperatively with an IA tear about $5 \mathrm{~mm}$ from the origin. There was no dissection flap found in ascending aorta or the arch. The tear was bypassed with a $12 \mathrm{~mm}$ Dacron graft from ascending aorta to IA distal to the tear with unilateral antegrade cerebral perfusion. The IA ostium was opened at the origin and the tear was closed under vision with plegeted prolene sutures. The rib injuries were managed conservatively. The postprocedure period was uneventful.

Endovascular treatment was not preferred because of the young age of the patient and it would have required a lifelong anticoagulation and multiple follow-up CTs.

Blunt thoracic outlet arterial injuries are rare with reported incidence of $<5 \%$. Although IA injury is second most common after aortic isthmus, there are less than 150 cases reported in the literature. ${ }^{1}$ IA ostium is most commonly

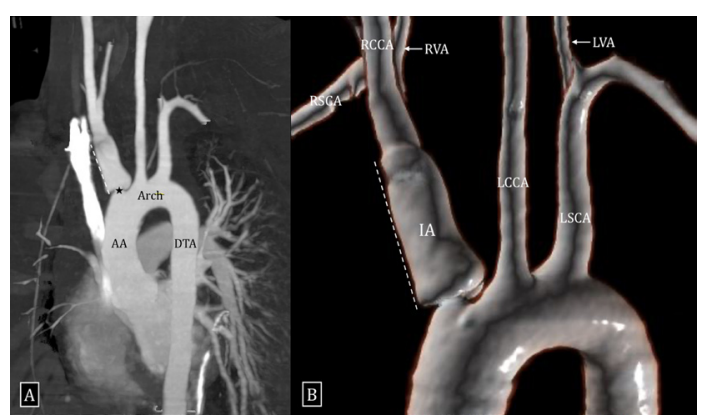

Figure 1 CT-maximum intensity projection $(A)$ and volume rendered images (B) show ostial dissection ( ${ }^{*}$ ) with pseudoaneurysm (dotted line) of innominate artery. Note the normal aortic isthmus, descending thoracic aorta and rest of arch vessels. AA, ascending aorta; DTA, descending thoracic aorta; IA, innominate artery; LCCA, left common carotid artery; LSCA, left subclavian artery; LVA, left vertebral artery; RCCA, right common carotid artery; RSCA, right subclavian artery; RVA, right vertebral artery. involved, as it is fixed to aortic arch as compared with distal IA. The ostium of IA gets stretched as it is trapped between the sternum or sternoclavicular joint anteriorly and vertebral column posteriorly with leftward shift of heart, resulting in tear or dissection with or without pseudoaneurysm formation. The management strategy depends on the severity of the injury. Simple dissections without significant haematoma in an asymptomatic patient can be managed conservatively. While, pseudoaneurysms should be treated on an urgent basis. The management options include open surgery, only endovascular or hybrid (surgery and endovascular management) approach. Open surgery is usually preferred as these injuries are often associated with aortic arch injuries which may or may not be well demonstrated on CT, which can be tackled during the open repair. Endovascular treatment with associated arch or ascending aortic injury would result in suboptimal treatment and require eventual open aortic repair. However, there was no ascending aorta or aortic arch injury found during the bypass surgery in our patient.

Endovascular treatment may be challenging due to lack of adequate proximal and distal landing zones; however, it can be offered to patients who are unsuitable for open surgery as a bridge therapy depending on the extension of the injury. The stent-graft can be deployed to completely exclude the pseudoaneurysm with or without extension of the stent graft to right common carotid artery or right subclavian artery distally with carotid-subclavian bypass. It can

\section{Learning points}

- Innominate artery (IA) injury although rare but important finding to look for while evaluating the patients of road traffic accidents. IA ostium is most commonly involved as it is fixed as opposed to more mobile distal IA segment.

- Simple dissections without haematoma can be managed conservatively, however, pseudoaneurysms should be treated on urgent basis.

- Open repair is the treatment of choice as it is often associated with aortic arch or ascending aortic injury with only endovascular or combined endovascular and surgical treatment can be offered to select group of patients. 


\section{Images in...}

also be extended into the aortic arch proximally if required in case of ostial injury similar to our patient. ${ }^{2}$

Contributors AAD: data collection and manuscript writing. SA: manuscript editing: SK and PR: manuscript proofreading.

Funding The authors have not declared a specific grant for this research from any funding agency in the public, commercial or not-for-profit sectors.

Competing interests None declared.

Patient consent for publication Not required.
Provenance and peer review Not commissioned; externally peer reviewed.

\section{ORCID iD}

Amit Ajit Deshpande http://orcid.org/0000-0001-7871-5688

\section{REFERENCES}

1 Davidović L, llić N, Cvetković $S$, et al. Blunt injury of the innominate artery and left innominate vein. Vascular 2011;19:223-5.

2 Dias-Neto M, Ramos JF, Teixeira JF. Blunt injury of the innominate artery: what surprises to expect? A case report. Vasc Endovascular Surg 2018;52:226-32.

Copyright 2021 BMJ Publishing Group. All rights reserved. For permission to reuse any of this content visit

https://www.bmj.com/company/products-services/rights-and-licensing/permissions/

BMJ Case Report Fellows may re-use this article for personal use and teaching without any further permission.

Become a Fellow of BMJ Case Reports today and you can:

- Submit as many cases as you like

- Enjoy fast sympathetic peer review and rapid publication of accepted articles

- Access all the published articles

- Re-use any of the published material for personal use and teaching without further permission

\section{Customer Service}

If you have any further queries about your subscription, please contact our customer services team on +44 (0) 2071111105 or via email at support@bmj.com.

Visit casereports.bmj.com for more articles like this and to become a Fellow 